\title{
SHOULD WE ABANDON THE NAME TITANOSAURIDAE? SOME COMMENTS ON THE TAXONOMY OF TITANOSAURIAN SAUROPODS (DINOSAURIA)
}

\author{
Leonardo SALGADO
}

CONICET. Universidad Nacional del Comahue. Buenos Aires 1400. (8300) Neuquén. Argentina. Isalgado@uncoma.edu.ar

\begin{abstract}
Salgado, L. 2003. Should we abandon the name Titanosauridae? Some comments on the taxonomy of titanosaurian sauropods (Dinosauria). [¿Deberíamos abandonar el nombre Titanosauridae? Algunos comentarios sobre la taxonomía de los saurópodos titanosaurios (Dinosauria).] Revista Española de Paleontología, 18(1), 1521. ISSN 0213-6937.
\end{abstract}

\begin{abstract}
Titanosaurs were the most abundant and widespread of Cretaceous sauropod dinosaurs. A derived subset of titanosaurian genera, historically termed the Titanosauridae, is beset with multiple taxonomic problems. Because the genus Titanosaurus is founded upon nondiagnostic material, the International Code of Zoological Nomenclature opposes the continued use of the term Titanosauridae. Nevertheless, the newly proposed Phylogenetic Code of Biological Nomenclature advocates the retention of Titanosauridae. To stabilize the taxonomy of derived titanosaurs, I consider Titanosauridae as a node-based taxon and Epachthosaurinae and Eutitanosauria as stem-based taxa, and thereby establish a node-stem triplet at Titanosauridae. I phylogenetically define additional titanosaurian clades including Titanosauroidea, Andesauroidea, Eutitanosauria, Saltasaurinae, and Opisthocoelicaudinae. Finally, I return "Titanosaurus" araukanicus to the genus Laplatasaurus.
\end{abstract}

Keywords: Titanosauridae, taxonomy, phylogenetic definitions.

\section{RESUMEN}

Los titanosaurios fueron los dinosaurios saurópodos cretácicos más abundantes y los más ampliamente distribuidos. Un subgrupo de titanosaurios derivados, históricamente conocidos como los Titanosauridae, posee múltiples problemas taxonómicos. Debido a que el género Titanosaurus está fundado a partir de material no diagnóstico, el Código Internacional de Nomenclatura Zoológica se opone al uso de Titanosauridae. De todas maneras, el recientemente propuesto Código Filogenético de Nomenclatura Biológica favorece el mantenimiento de ese término. Para estabilizar la taxonomía de los titanosaurios derivados, se considera Titanosauridae como un taxón basado en el nodo (node-based taxon) y Epachthosaurinae y Eutitanosauria como taxones basados en la rama (stem-based taxon) y, de este modo, se establece un triplete nodo-rama (NST) en la base de Titanosauridae. Se definen filogenéticamente clados de titanosaurios adicionales, incluyendo Titanosauroidea, Andesauroidea, Eutitanosauria, Saltasaurinae y Opisthocoelicaudinae. Finalmente, "Titanosaurus" araukanicus es regresado a Laplatasaurus.

Palabras clave: Titanosauridae, taxonomía, definiciones filogenéticas.

\section{INTRODUCTION}

The monophyly of Titanosauridae [defined by Salgado (2000) as titanosaurian sauropods closer to Saltasaurus Powell than to Andesaurus Calvo and Bonaparte] has been explicitly or implicitly accepted by virtually all authors (e.g., Huene, 1929; Powell, 1986; McIntosh, 1990; Salgado et al., 1997; Bonaparte, 1999). However, several taxa traditionally included in this clade of sauropod dinosaurs are based upon material that is not diagnostic. The case of Titanosaurus indicus Lydekker, the type species of the genus Titanosaurus Lydekker, illustrates this situation. Lydekker (1877) diagnosed Titanosaurus on the basis of procoely in its caudal vertebrae, which at the time was known only in that taxon. Since 1877, a number of forms related to Titanosaurus indicus have been discovered, and it is now known that procoelous caudals characterize a large group of sauropods: the Titanosauridae.

In view of this situation, an increasing number of 
authors have avoided the name Titanosauridae and used alternative names, in order to satisfy the standards of the International Code of Zoological Nomenclature.

In this paper I summarize the many diagnoses of Titanosauridae, Titanosaurus and the species assigned to it, and propose new phylogenetic definitions for Titanosauria and clades within. My aim is to standardize the usage of names in order to prevent confusion, and, at the same time, to maintain, as much as is possible, the terminology formerly proposed.

\section{HISTORY OF THE GENUS TITANOSAURUS AND THE TITANOSAURIDAE}

The type species of Titanosaurus, Titanosaurus indicus, was founded upon two procoelous caudal vertebrae (designated as the holotype) and an isolated femur (designated as the cotype) from the Lameta Formation at Jabalpur, India (Lydekker, 1877). Although he did not provide a formal diagnosis of Titanosaurus, Lydekker (1877) described the caudal vertebrae of Titanosaurus indicus as laterally compressed and strongly procoelous. He stated "the forms of the articular surfaces of the vertebrae are quite sufficient to distinguish the Indian genus from all other genera of Dinosauria" (Lydekker, 1877: 40). In this manner, although Titanosaurus included only one species, Lydekker understood that procoely was a character of the genus.

Later, Lydekker (1879) applied the same generic name to a new species (Titanosaurus blanfordi Lydekker), based on another isolated procoelous caudal vertebra from the Lameta Formation, at Pisdura, India.

In a book that appeared in 1888, Lydekker announced the discovery of bones referable to Titanosaurus sp. from the Wealden of the Isle of Wight [subsequently, Friederich von Huene erected a new species, Titanosaurus valdensis Huene, the first European titanosaurid to be recognized (Huene, 1929)]. Therein, Lydekker provided short characterizations of Titanosaurus and Titanosaurus indicus, which can be regarded as diagnoses. For Titanosaurus: "postmedian caudal vertebrae procoelous; femur apparently like that of Cetiosaurus" (Lydekker, 1888: 134). For Titanosaurus indicus: "centra of posterior caudal vertebrae much compressed laterally, and facets for chevrons strongly marked" (Lydekker, 1888: 134). Thus, "caudal procoely", was confirmed as a character applicable at the genus level. In turn, the lateral compression of the caudal vertebrae was established by Lydekker (1888: 134), as part of the diagnosis of the type species (Titanosaurus indicus).

When the family Titanosauridae was formally erected by Lydekker in 1893, Titanosaurus contained four species: Titanosaurus australis Lydekker and Titanosaurus (?) nanus Lydekker (based on one cervical and two dorsal vertebrae) from the Upper Cretaceous of Patagonia, and the two Indian species mentioned above (Lydekker, 1893). Titanosauridae also included
Argyrosaurus superbus Lydekker, 1893 and Microcoelus patagonicus Lydekker, 1893, the first titanosaurids to receive generic names other than Titanosaurus (Hypselosaurus Matheron, 1869, a nomen dubium, was in fact named earlier, but was not recognized as a member of the Titanosauridae until the early $20^{\text {th }}$ century [Huene, 1929]).

Although Lydekker (1893) stated that Titanosaurus australis and Titanosaurus indicus belonged to the same genus, he noted differences in caudal morphology between the two taxa. In Titanosaurus indicus, distal caudal vertebrae were characterized by strong lateral compression (it must be remembered that the character was first proposed as diagnostic of the type species in 1877), whereas in Titanosaurus australis such compression was absent.

Lydekker (1893: 3) diagnosed the new family Titanosauridae as follows: "...sauropodous dinosaurs in which the caudal vertebrae, with the exception of the first, are procoelous, the presacrals opisthocoelous, and the lumbars without lateral cavities; the superior extremities of the chevron-bones being open." Thus, the main diagnostic character of Titanosaurus and Titanosaurus indicus proposed by Lydekker in 1877, the procoelous condition, was subsumed in his 1893 diagnosis of Titanosauridae. This reflected a change from his earlier opinion, as stated in his 1888 paper ["the procoelous character of the caudals has been regarded as indicating a distinct family, but this does not appear a necessary conclusion" (Lydekker, 1888: 134)].

In his 1929 monograph "Los Saurisquios y Ornitisquios del Cretáceo Argentino" Huene accepted the validity of both Titanosaurus (creating the new species Titanosaurus robustus) and Argyrosaurus, and erected three more titanosaurid genera: Campylodon Huene (later emended to Campylodoniscus by Kuhn [1961]), Antarctosaurus Huene (with the species $A$. wichmannianus Huene and A. giganteus Huene), and Laplatasaurus Huene. The last was named for remains from Cinco Saltos (in Río Negro Province), and a series of fragmentary bones originally assigned by Lydekker to Titanosaurus from several northern Patagonian localities. Huene perceived that the family Titanosauridae included a large diversity of genera (7 in total).

Huene (1929) was the first to recognize the close relationships of Macrurosaurus semnus Seeley from the Cenomanian of Barnwell (England), originally described by Seeley in 1869, and Hypselosaurus priscus (France), described by Matheron in 1869, with the Titanosauridae.

Huene accepted the inclusion of Titanosaurus australis and Titanosaurus indicus within the same genus, based on their caudal morphology: "It is always a risky thing to express identity founded only on middle caudal vertebrae. However, the characteristic features are so extraordinary and attractive that, at the moment, they can and they should be enough to satisfy us in this point" (p. 90). According to Huene (p. 90), the only difference between Titanosaurus australis and Titanosaurus indicus was the lateral compression of the caudal centra of the last species, as noted earlier by Lydekker (1893). 


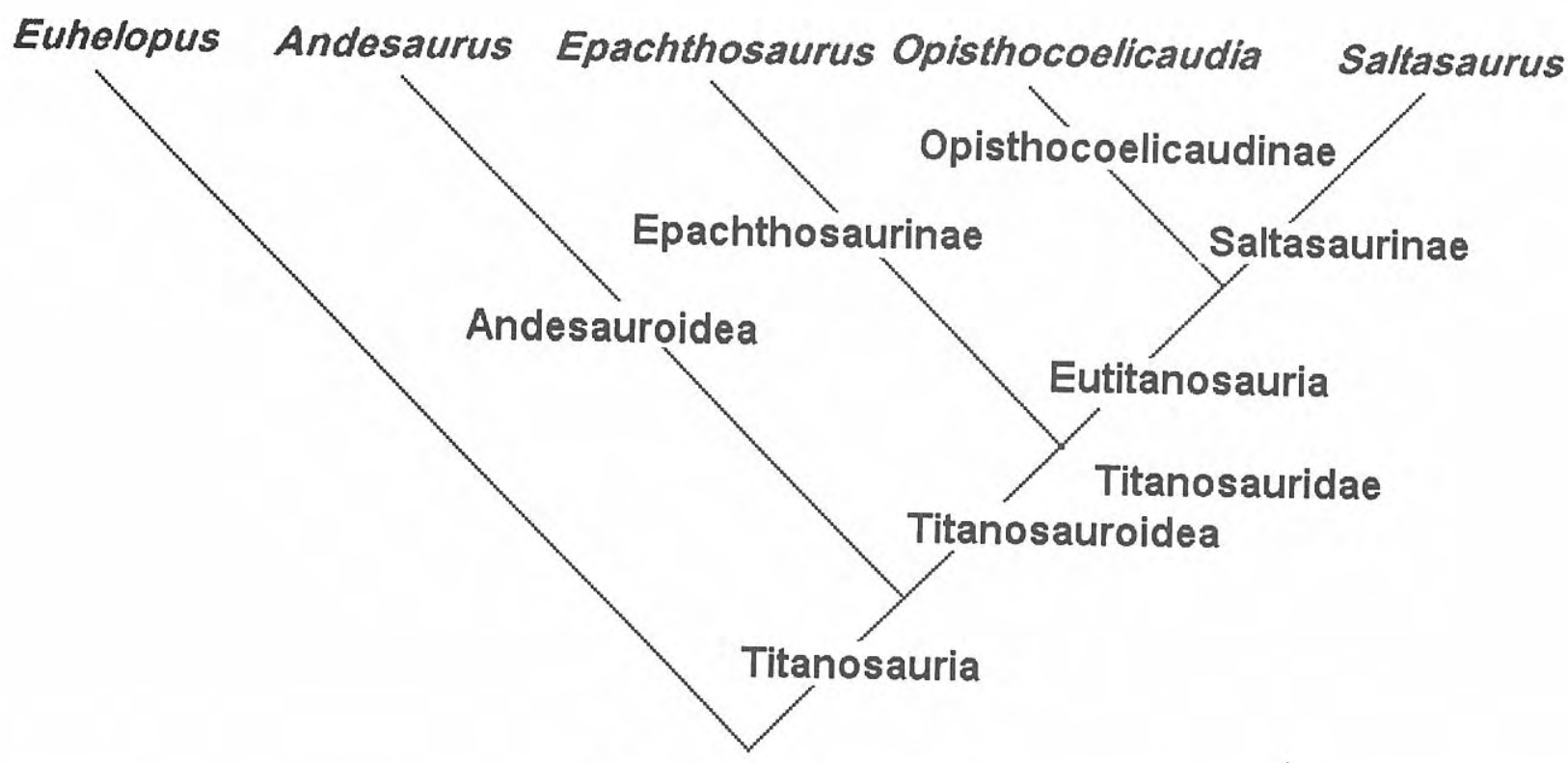

Somphospondyli

Figure 1. Phylogenetic relationships of titanosaurs and clade names within Titanosauria, according to the proposal given in the text.

Likewise, the differences invoked to separate Titanosaurus from Laplatasaurus were observed in their caudal morphology. Huene's diagnosis of Titanosaurus included the following caudal characters: "(the caudal vertebrae have the) posterior articular cone pointed and wide (with the exception of the subspherical first)" (p. 84), whereas the diagnosis of Laplatasaurus included a "high and pointed articular cone" (p. 85). For the characterization of the caudal vertebrae in titanosaurids, Huene stated that "the following (vertebrae distal to the first caudal) are procoelous with the articular cone behind" ( $p .86$ ), that is, for him, the presence of procoelous caudal vertebrae was indicative of Titanosauridae.

Huene (1929) also observed differences between Titanosaurus madagascariensis Deperet, 1896 and Titanosaurus australis+Titanosaurus indicus; for this reason, he proposed to reassign the first species to the genus Laplatasaurus, though he never provided adequate evidence of a close relationship with Laplatasaurus araukanicus (the type species of the genus).

Huene and Matley (1933) described two vertebrae and many poorly preserved and dissociated appendicular bones from Bara Simla and Silondi, India, and assigned all of this material to Titanosaurus indicus. These authors (op.cit.: 55) provided a diagnosis of Titanosaurus indicus: "post-median procoelous caudal vertebrae with flat, lateral sides (...) (1), a longitudinal groove below (2), and a low longitudinally stretched neural arch growing only from the anterior half of the centrum (3). The deeply bifurcated and open haemapophyses of this region have double articulations on each ramus (4). Tibia with thick head (5). Fibula also very broad and with a strongly developed attachment for the peroneus muscle (6). Femur (if belonging to it) thick and very broad in upper part
(7)". Actually, most of these characters are present in nearly all titanosaurids (Powell, 1986; McIntosh, 1990). Huene and Matley (1933) also referred the vertebrae described by Lydekker (1879) as Titanosaurus blanfordi to cf. Laplatasaurus madagascariensis Deperet.

In his exhaustive revision of South American titanosaurids, Powell (1986) did not invalidate the genus Titanosaurus nor its type species (Titanosaurus indicus). Instead, he advocated a change in nomenclature in order to define Titanosaurus upon observations made principally on caudal morphology. First, Powell (1986, 1992) observed that Titanosaurus australis and Titanosaurus robustus, with their low caudal vertebrae with dorsoventrally convex lateral faces, had more in common with Saltasaurus loricatus Bonaparte and Powell, 1980 (a species from northwestern Argentina), than with Titanosaurus indicus. He then created a new subfamily, the Saltasaurinae, to accomodate these three species. In turn, Powell (1986) grouped Laplatasaurus araukanicus (Huene, 1929), Aeolosaurus rionegrinus Powell, 1987 and Titanosaurus indicus in the subfamily Titanosaurinae, united by their high caudal vertebrae with dorsoventrally concave lateral surfaces. Second, given the fact that Titanosaurus australis and Titanosaurus robustus pertain to a different subfamily than Titanosaurus indicus, Powell named the genus Neuquensaurus to be applied to the first two species. He replaced Laplatasaurus with Titanosaurus; Titanosaurus araukanicus was thus the name proposed for Laplatasaurus araukanicus. The names Titanosaurus and Titanosaurinae, thus, were reserved for sauropods with the same caudal morphology as the type species: Titanosaurus indicus.

Jain and Bandyopadhyay (1997) described a new species (Titanosaurus colberti Jain and Bandyopadhyay) 
based on a single, partially disarticulated specimen from Dongargaon (India). It is undoubtedly the best-preserved specimen from the Cretaceous of India assigned to Titanosaurus. These authors recognized the presence of three species of Titanosaurus in India: Titanosaurus indicus, Titanosaurus blanfordi and Titanosaurus colberti. They stated that differences between these species are found in the shape of the middle caudal centra, the diameter of the articular faces of the centra, and in the placement of the facets for the haemapophyses. Jain and Bandyopadhyay (1997) accepted Huene's (1929) proposal that Titanosaurus australis and Laplatasaurus araukanicus were valid species, and assumed a phylogenetic relationship between certain Patagonian and Indian titanosaurs (the species of the genus Titanosaurus). They provided a new diagnosis of Titanosaurus: "Large advanced sauropods with strongly procoelous caudals throughout the series (1); cervical and dorsal vertebrae opisthocoelous with well-marked pleurocoels (2); transverse process of cervicals robust, directed laterally, very wide posteriorly in the shoulder region (3); transverse processes in dorsals narrow and directed outward and little upward (4); neural spine not bifid, directed posteriorly (5); sacrum with six co-ossified vertebrae and ribs (6); first and sixth sacral centra convex anteriorly and posteriorly respectively (7); midcaudal and part of distal caudals with prominent variable chevron facets (8); robust prezygapophyses extending to the anterior margin of the caudals (9); first sacral rib extended outward below the iliac blade (10); preacetabular process of the ilium projecting outward becoming almost horizontal (11); bladelike ischium transversely expanded in the middle (12); shaft of slender radius perpendicular to the axis of the expanded distal ends (13); ulna robust and triangular in cross section (14); humero-femoral ratio 0.74 (15); tibio-femoral ratio 0.65 (16); femur without any lateral prominence (17); moderate development of nuchal crest of braincase (18); transverse ridge on parietal (19); high buttress ridge below the paraoccipital process (20)." (p. 134).

However, many of these characters $(1-8,10-12,14)$ were also proposed as diagnostic of the species Titanosaurus colberti (Jain and Bandyopadhyay, 1997: 117), or are widely distributed within the Sauropoda (111). Others have an unknown distribution within Titanosauridae (13-20). At the moment, there is no strong evidence to support the referral of the three species from India to the same genus. Furthermore, the presence of more than one titanosaurid species in India has not yet been fully demonstrated, at least by published osteological evidence (see Sahni et al., 1994 for an evaluation of the ichnological evidence). This conclusion agrees with that of Chatterjee and Rudra (1996).

\section{THE ALTERNATIVES TO TITANOSAURIDAE}

Because the vertebrae upon which Titanosaurus indicus was erected in 1877 do not show clear differences with other non-saltasaurine titanosaurids, both Titanosaurus indicus and Titanosaurus should be considered nomina dubia. Moreover, although the name Titanosauridae has a long usage, it could be abandoned, because it was founded upon a poorly-known type genus (International Code of Zoological Nomenclature 1999 [ICZN], Article 39, Recommendation 64A: 65).

The authors that have discontinued the use of the name Titanosauridae have employed a series of alternative, though not always equivalent, designations.

The first author to dismiss the name Titanosauridae was Sereno (1998). He and others (Wilson and Carrano, 1999; Wilson et al., 1999) used the term Saltasauridae instead of Titanosauridae. Saltasauridae was defined as "Opisthocoelicaudia, Saltasaurus, their most recent common ancestor and all of its descendants".

Sereno's Saltasauridae was conceived to encompass "nearly all titanosaurs with the unusual biconvex caudal vertebra". He acknowledged that this clade is not based on diversity, morphology, or tradition, the three criteria for the emplacement of a "node-stem triplet" (NST).

Bonaparte (1999) used the terms Titanosauridae and Andesauridae, both grouped within the Titanosauria. He did not define these groups phylogenetically but rather by their taxonomic content, including Argentinosaurus Bonaparte and Coria and Andesaurus Calvo and Bonaparte, 1991 within the Andesauridae, and other Late Cretaceous titanosaurs in the Titanosauridae.

Sanz et al. (1999) avoided the use of Titanosauridae, employing terms such as Titanosauroidea, Titanosauria and Eutitanosauria. Sanz et al.'s (1999) Titanosauria (defined as the most recent common ancestor of Epachthosaurus Powell, 1990, Saltasaurus Bonaparte and Powell, 1980, Argyrosaurus Lydekker, 1893, Lirainosaurus Sanz, Powell, Le Loeuff, Martínez and Pereda-Suberbiola, 1999, plus the Peirópolis titanosaur and all of its descendants) is basically equivalent to Titanosauridae of Salgado et. al (1997) (defined as the clade including the most recent common ancestor of Epachthosaurus sciuttoi, Malawisaurus dixeyi, Argentinosaurus huinculensis, Titanosaurinae indet. (DGM "Serie B), Opisthocoelicaudia skarzynskii, Aeolosaurus, Alamosaurus sanjuanensis and Saltasaurinae and all of its descendants). In turn, based on its taxonomic content, Sanz et al.'s (1999) Titanosauroidea is equivalent to Upchurch's (1995) Titanosauroidea, although neither of these authors defined the taxon phylogenetically [Upchurch (1995), contrary to Sanz et al. (1999) employs both Titanosauroidea and Titanosauridae]. Finally, Eutitanosauria is defined as "the most recent common ancestor of Saltasaurus, Argyrosaurus, Lirainosaurus, plus the Peirópolis titanosaur and all its descendants." (Sanz et al., 1999: 252). This clade does not have a clear counterpart in other phylogenetic schemes. Based on its taxonomic content and diagnosis, it would be equivalent to "unnamed taxon II" of Salgado et al. (1997: 22).

Titanosauridae was also not used by Curry Rogers and Forster (2001). The new Malagasy genus Rapetosaurus Curry Rogers and Forster is designated a saltasaurine. 
However, Curry Rogers and Forster's Saltasaurinae is not equivalent to Powell's Saltasaurinae; paradoxically, Curry Rogers and Forster's Saltasaurinae is more generically inclusive than Sereno's Saltasauridae.

Smith et al.'s (2001) usage of Titanosauridae is basically the same as that of Salgado et al. (1997).

\section{DISCUSSION}

If the preexisting code based upon the Linnaean system of nomenclature is to be followed, any invalid name should be replaced by another of the same hierarchical category. In other words, the invalid name of a group (namely, a family name) should be replaced by a new name, which must be applicable to the same group. The taxonomic change proposed by Sereno (1998) is twofold: first, an invalid name (Titanosauridae) is abandoned, and second, a new group, less inclusive than Titanosauridae, is created, to which a new name, Saltasauridae, is applied. According to Sereno's (1998) phylogenetic definition of the group ("Opisthocoelicaudia, Saltasaurus, their most recent ancestor and all its descendants"), Saltasauridae is a group less inclusive than Titanosauridae. In short, Saltasauridae and Titanosauridae are not equivalent groups. Most recent titanosaur phylogenies consider Opisthocoelicaudia as the sister group of Alamosaurus Gilmore plus Saltasaurinae sensu Powell (1992) (Salgado, 2000), or even as the sister group of Saltasaurinae sensu Powell (1992) (Curry Rogers and Forster, 2001). If accepted, the changes proposed by Sereno would exclude a number of taxa traditionally grouped in the Titanosauridae from the Saltasauridae, including Aegyptosaurus Stromer, 1932, Aeolosaurus Powell, 1987, Antarctosaurus, Argyrosaurus, Epachthosaurus, Magyarosaurus Huene, 1932, Malawisaurus Jacobs, Winkler, Downs and Gomani, 1993, Paralititan Smith, Lamanna, Lacovara, Dodson, Smith, Poole, Giegengack and Attia, 2001, Titanosaurus colberti Jain and Bandyopadhyay, and the Peiropolis titanosaur(s).

Sereno (1998) justified the first change (the abandonment of the name Titanosauridae) with the invalidity of the generic name Titanosaurus. The second (the erection of a new group, the Saltasauridae) was claimed to be based upon the necessity to stabilize the higher taxonomy of derived titanosaurs (traditionally designated titanosaurids) and the inconvenience of situating a NST at the base of Titanosauria, which would require using a poorly-known genus, such as Andesaurus, as a reference taxon.

Sereno's (1998) first argument, that the name Titanosauridae is unavailable, may not be tenable. According to the newly proposed Phylogenetic Code of Biological Nomenclature, or PhyloCode, "supraspecific names do not have types in the sense that this term is used in the preexisting codes." (Cantino and de Queiroz, 2000). Conversely, the PhyloCode also states that "a clade whose name is converted from a genus name under a preexisting code, or is derived from the stem of a genus name, should include the type of the genus name. Therefore, when a clade name is converted from a preexisting genus name or is a new or converted name derived from the stem of a genus name, the definition of the clade must use the type species of that genus as an internal specifier" (Cantino and de Queiroz, 2000: Article 11.8). If this recommendation is followed, Titanosaurus indicus should be used as an internal specifier of those clades whose names are derived from Titanosaurus including Titanosauriformes, Titanosauria, Titanosauroidea, Titanosauridae, and Eutitanosauria. However, because Titanosaurus indicus is a nomen dubium, it cannot be used as an internal specifier for any clade name. That notwithstanding, the PhyloCode (Recommendation $11.8 \mathrm{~B}$ ) also states that "If it is questionable whether the type specimen of a preexisting name belongs to the clade to be named (e.g., because of the fragmentary nature of the specimen), then that preexisting name (or its type) should not be used as a specifier ... and the corresponding name should not be converted to a clade name." This is not the case of the type species of Titanosaurus; because of its procoelous condition, it is clearly a titanosaurian.

Finally, in Recommendation 10A, the PhyloCode states that "clade names should be selected in such a way as to minimize disruption of current usage". Therefore, according to this recommendation of the PhyloCode, the name Titanosauridae should not necessarily be abandoned.

With respect to the second argument, I believe that, if the use of the name Titanosauridae is maintained, as stated above, it is possible to place a NST at its base, and thus stabilize the higher taxonomy of titanosaurs. To do this, however, a node-based definition of Titanosauridae is needed. Salgado's (2000) stem-based definition potentially includes titanosaurs with amphiplatyan to platycoelous middle caudal vertebrae, a situation that should be avoided. In contrast, Salgado et al.'s (1997) node-based definition seems more adequate for this purpose. Therein, Epachthosaurus is chosen as reference taxon for the definition of Titanosauridae. However, to place a NST at the base of Titanosauridae (Titanosauridae $=$ Epachthosaurinae + Eutitanosauria $),$ a new clade, Epachthosaurinae, and Eutitanosauria should be defined as stem groups. The NST is not diversitybased (see Sereno, 1998: 54), given the single genus Epachthosaurus on one side of the dichotomy.

In summary, there is no need to abandon the traditional titanosaurian group Titanosauridae. It should be defined to include only titanosaurians with procoelous middle caudal vertebrae (the opisthocoelous condition in Opisthocoelicaudia apparently evolved from the procoelous condition). In this way, the name Titanosauridae and its most commonly associated character, caudal procoely, would remain in association.

\section{CONCLUSION: A UNIFYING PROPOSAL}

We propose to adopt the following taxonomic scheme for Titanosauria (Figure 1): 
Titanosauria Bonaparte and Coria, 1993

Definition: All somphospondylians closer to Saltasaurus than to Euhelopus Romer.

Titanosauroidea Upchurch, 1995

Definition: All titanosaurs closer to Saltasaurus than to Andesaurus.

Andesauroidea nov.

Definition: All titanosaurs closer to Andesaurus than to Saltasaurus.

Titanosauridae Salgado, Coria and Calvo, 1997

Definition: Epachthosaurus, Saltasaurus, their most recent common ancestor and all of its descendants.

Epachthosaurinae nov.

Definition: All titanosaurs closer to Epachthosaurus than to Saltasaurus.

Eutitanosauria Sanz, Powell, Le Loeuff, Martínez and Pereda-Suberbiola, 1999

Definition: All titanosaurs closer to Saltasaurus than to Epachthosaurus.

Saltasaurinae Powell, 1992 (sensu Sereno, 1998)

Definition: All eutitanosaurs closer to Saltasaurus than to Opisthocoelicaudia.

Opisthocoelicaudiinae Sereno, 1998

Definition: All eutitanosaurs closer to Opisthocoelicaudia than to Saltasaurus.

\section{FINAL COMMENT}

The group Titanosaurinae (including the genera Titanosaurus and Aeolosaurus), as defined by Powell (1986), was recognized as a paraphyletic assemblage by Salgado and Calvo (1993) and Salgado et al. (1997), because its supposedly diagnostic characters (high caudal vertebrae with dorsoventrally concave lateral faces, narrow ventral faces and laterally compressed neural spines) are present in a wide range of sauropods. Titanosaurus is also paraphyletic, since the diagnoses of
Titanosaurus and Titanosaurinae are basically the same. Given the fact that Titanosaurus indicus and Laplatasaurus araukanicus do not form a monophyletic group (because there are no valid diagnostic characters of Titanosaurus), the replacement of this last denomination with Titanosaurus araukanicus was not justified.

Therefore, I propose to exchange the name Titanosaurus araukanicus Huene for its senior synonym, Laplatasaurus araukanicus Huene. The type material of this species is the same as proposed by Powell (1986: 8283).

\section{ACKNOWLEDGEMENTS}

I very much appreciate the review of this manuscript by Matthew Lamanna.

\section{BIBLIOGRAPHY}

Bonaparte, J. F. 1999. Evolución de las vértebras presacras en Sauropodomorpha. Ameghiniana, 36, 115-187.

Bonaparte, J.F. y Coria, R.A. 1993. Un nuevo y gigantesco saurópodo titanosaurio de la Formación Río Limay (Albiano-Cenomaniano) de la Provincia del Neuquén, Argentina. Ameghiniana, 30, 271-282.

Bonaparte, J.F. and Powell, J.E. 1980. A continental assemblage of tetrapods from the Upper Cretaceous beds of the El Brete, Northwestern Argentina (SauropodaCoelurosauria-Carnosauria-Aves). Mémoires de la Société Géologique de France, N.S., 139, 19-28.

Calvo, J.O. y Bonaparte, J.F. 1991. Andesaurus delgadoi gen. et sp. nov. (Saurischia-Sauropoda), dinosaurio Titanosauridae de la Formación Río Limay (AlbianoCenomaniano), Neuquén, Argentina. Ameghiniana, 28, 303-310.

Cantino, P. D. and de Queiroz, K. 2000. PhyloCode: A Phylogenetic Code of Biological Nomenclature [http://www.ohiou.edu/phylocode/].

Chatterjee, S. and Rudra, D. K. 1996. KT events in India: impact, rifting, volcanism and dinosaur extinction. Memoirs of the Queensland Museum 39, 489-532.

Curry Rogers, K. and Forster, C. A. 2001. The last of the dinosaur titans: a new sauropod from Madagascar. Nature, 412, 530-534.

Depéret, Ch. 1896. Note sur les dinosauriens sauropodes \& théropodes du Crétacé Supérieur de Madagascar. Bulletin de la Société Géologique de France. 3ra. série, 24, 176194.

Huene, F. von, 1929. Los Saurisquios y Ornitisquios del Cretáceo Argentino. Anales del Museo de La Plata, (ser.2) 3, 1-196.

Huene, F. 1932. Die fosil Reptil-Ordnung Saurischia, ihre Entwicklung und geschichte. Monographen zur geologie und palaeontologie, (1) 4, 1-361.

Huene, F. von and Matley, C.A. 1933. The Cretaceous Saurischia and Ornitischia of the Central Provinces of India. Memoirs of the Geological Survey of India, 21, 174. 
International Commission on Zoological Nomenclature. 1999. International Code of Zoological Nomenclature. Fourth Edition. The International Trust for Zoological Nomenclature, $306 \mathrm{pp}$.

Jacobs, L.L., Winkler, D.A., Downs, W.R. and Gomani, E. 1993. New material of an Early Cretaceous titanosaurid sauropod dinosaur from Malawi. Palaeontology, 36, 523-534.

Jain, S. L. and Bandyopadhyay, S. 1997. New titanosaurid (Dinosauria: Sauropoda) from the Late Cretaceous of Central India. Journal of Vertebrate Paleontology, 17, 114-136.

Kuhn, O. 1961. Die Familien der rezenten und fossilen Amphibien und Reptilien. Meisenbach, Bamberg, 79 pp.

Lydekker, R. 1877. Notices of new and other Vertebrata from Indian Tertiary and Secondary Rocks. Records of the Geological Survey of India, 10, 30-43.

Lydekker, R. 1879. Indian pre-Tertiary Vertebrata. Fossil Reptilia and Batrachia. Paleontologia Indica, (ser.4) 1, $1-36$.

Lydekker, R. 1888. Catalogue of the fossil Reptilia and Amphibia in the British Museum. Pt. I. Containing the orders Ornithosauria, Crocodilia, Dinosauria, Squamata, Rhynchocephalia, and Proterosauria. British Museum of Natural History. London, 309 pp.

Lydekker.R. 1893. Contributions to the study of the fossil vertebrates of Argentina. I. The Dinosaurs of Patagonia. Anales del Museo de La Plata. Sec. Paleon., 2, 1-14.

Matheron, P. 1869. Note sur les reptiles des dépots fluviolacustres crétacés du bassin á lignite de Fuveau. Bulletin de la Societé Gélogique de France (série 2) 26, 781-795.

McIntosh, J.S., 1990. Sauropoda. In: The Dinosauria (Eds. D.B. Weishampel, P. Dodson and H. Osmolska). University of California Press, Berkeley, 346-407.

Powell, J.E. 1986. Revisión de los titanosáuridos de América del Sur (Thesis unpublished). Universidad Nacional de Tucumán. Argentina, 340 pp.

Powell, J.E. 1987. The Late Cretaceous Fauna of Los Alamitos, Patagonia, Argentina. Part. VI. The titanosaurids. Revista del Museo Argentino de Ciencias Naturales, 3(3), 147-153.

Powell, J.E. 1990. Epachthosaurus sciuttoi gen. et sp. nov. un nuevo dinosaurio saurópodo del Cretácico de Patagonia (Provincia del Chubut, Argentina). Actas 5to. Congreso Argentino de Paleontología y Bioestratigrafía, 1, 123-128. Tucumán.

Powell, J.E. 1992. Osteología de Saltasaurus loricatus (Sauropoda-Titanosauridae) del Cretácico Superior del Noroeste argentino. In: Los dinosaurios y su entorno biótico (Eds. J. L. Sanz and A.D. Buscalioni). Instituto Juan de Valdés, Cuenca, 166-230.
Sahni, A., Tandon, S.K., Jolly, A., Bajpai, S., Sood, A. and Srinivasan, S. 1994. Late Cretaceous dinosaur eggs and nesting sites from the Deccan volcano-sedimentary province of peninsular India. In: Dinosaur Eggs and Babies (Eds. K. Carpenter, J. Horner \& K.F. Hirsch), Cambridge University Press, 204-226.

Salgado, L. 2000. Evolución y Paleobiología de los saurópodos Titanosauridae (Thesis Unpublished). Universidad Nacional de La Plata. 300 pp.

Salgado, L. and Calvo, J.O. 1993. Report of a sauropod with amphiplatyan mid-caudal vertebrae from the Late Cretaceous of Neuquén Province (Argentina). Ameghiniana, 30, 215-218.

Salgado, L., Coria, R. A. and Calvo, J.O. 1997. Evolution of titanosaurid sauropods. I: Phylogenetic analysis based on the postcranial evidence. Ameghiniana, 34, 3-32.

Sanz, J. L., Powell, J. E., Le Loeuff, J., Martínez, R. and Pereda-Suberbiola, X. 1999. Sauropod remains from the Upper Cretaceous of Laño (Northcentral Spain), titanosaur phylogenetic relationships. Estudios del Museo de Ciencias Naturales de Álava, 14 (Núm.Espec. 1), 235-255.

Seeley, H.G. 1869. Index to the fossil remains of Aves, Ornithosauria and Reptilia, from the Secondary system of strata arranged in the Woodwardian Museum of the University of Cambridge. Cambridge, $143 \mathrm{pp}$.

Sereno, P.C. 1998. A rationale for phylogenetic definitions, with application to the higher-level taxonomy of Dinosauria. Neues Jahrbuch fur Geologie und Paläontologie Abhandlungen, 210, 41-83.

Smith, J. B., Lamanna, M. C., Lacovara, K .J., Dodson, P., Smith, J. R., Poole, J. C., Giegengack, R. and Attia, Y. 2001. A giant sauropod dinosaur from an Upper Cretaceous Mangrove deposit in Egypt. Science, 292, 1704-1706.

Stromer, E. 1932. Wirbeltierreste der Baharije-Stufe (unterstes Cenoman). 11. Sauropoda. Abhhandlungen der Bayerischen Akademie der Wissenschaften, Mathematisch-naturwissenschaftlichen Abteilung, 10, 121.

Upchurch, P. 1995. The evolutionary history of sauropod dinosaurs. Philosophical Transactions of the Royal Society of London, B 349, 365-390.

Wilson, J.A. and Carrano, M.T. 1999. Titanosaurs and the origin of "wide-gauge" trackways: a biomechanical and systematic perspective on sauropod locomotion. Paleobiology, 25, 252-267.

Wilson, J.A., Martínez, R.N. and Alcober, O. 1999. Distal tail segment of a titanosaur (Dinosauria: Sauropoda) from the Upper Cretacoeus of Mendoza, Argentina. Journal of Vertebrate Paleontology, 19, 591-594. 